\title{
The role of celebrities for the image of endorsed products
}

\author{
Adriana OPRIS \\ Bucharest University of Economic Studies, Bucharest, Romania \\ adriana.opris@yahoo.com \\ Corina PELAU \\ Bucharest University of Economic Studies, Bucharest, Romania \\ corina.pelau@fabiz.ase.ro \\ Laura LAZAR \\ Bucharest University of Economic Studies, Bucharest, Romania \\ laura_lazar10@yahoo.com
}

\begin{abstract}
Celebrities are, in recent years, a popular way to draw the consumer's attention to an advertisement. In an age with an abundance of details and advertising, the celebrities 'glamour has the power to increase the advertised product's exposure and to attract the attention of the consumer. Several researches have focused on analyzing the impact of celebrity endorsement on the success of brands by pointing out the importance of the match between the celebrities' personality and the image of the endorsed brand. Besides the positive aspects, there have been also pointed out the different disadvantages of using celebrities in advertising such as the overshadowing effect or the exaggerated costs involved. The results of our quantitative research have shown that, although there is not a high declared interest in celebrity endorsement, it has a role especially in shaping the social status of the consumer and that women are more attracted by celebrity endorsed product in comparison to men. :
\end{abstract}

Keywords: celebrity endorsement, consumer, advertising, attention, eye-tracking, neuroscience, brand identity, human brands, social media, commitment.

\section{Introduction}

In the contemporary marketplace, celebrities are a common feature, sometimes becoming the face, or logo, not only of consumer products and brands, but of organizations themselves. For example, in Australia, Hugh Jackman is the face of Lipton Iced Tea, Nicole Kidman appears in Nintendo DS commercials and George Clooney teams up of Nespresso coffee with John Malkovich. Brands make use of famous and likable celebrities by exploiting their popularity (Keller, 2008).

The endorsement of celebrities in advertising has several advantages and disadvantages and it is important to use them wisely in advertising in order to achieve the desired success. On one hand celebrities have a higher potential to attract the consumer's attention, because many of these celebrities represent a role-model in the society. Besides the social characteristics of individuals, develop a natural need to exchange information on societal issues in form of gossip. On the other hand, celebrities might have an over-shadowing effect by attracting the entire attention of an advertising and by eclipsing the advertised product (Nistoreanu, et al. 2019).

In this paper we will focus on the results of a research measuring the attitudes and the perception of the consumers towards celebrities and their impact on the perception of the endorsed product or brand. Several researches have shown so far, that older people are more influenced by celebrity endorsement (Lazar \& Nistoreanu, 2019) and that younger people are 
more influenced by brands (Popa \& Pelau, 2016). However it is important to permanently adopt new marketing instruments according to the expectations of the society (Pop, 2018).

\section{Literature review regarding the importance of celebrity endorsement}

In the world where customers have many choices, advertisement is one approach that businesses usually use to achieve product differentiation. Celebrity endorsement is very common among all advertising campaigns and is widely adopted (Erdogan et al., 2001) for almost every type of product or service available (Doss, 2011).

A celebrity is a famous person receiving public attention. For this reason, it is very effective to use famous advertisers in ads, because they attract the attention of customers through their name and image. The famous people are like human brands because they become branding and marketing experiments with their actions and appearances on stage, as well as with their private life activity and their online activity. The daily life of the celebrity and its decisions are private, but these are conducted in public. Those acts build brand names so that through celebrity endorsement, the companies sell different products (Holmes \& Redmond, 2014). A famous person has a better influence on the purchasing behavior of a person than a normal person according to McCracken (1989). Nevertheless, he also thinks the commercials with celebrities are characteristic of modern marketing. The marketing personalities can pass their established identity on the goods being marketed. This thing is for the benefit of customers.

Celebrities are a phenomenon in advertising today. But, since the commercial occurs, these exist. This type of advertising has a high potential. The so-called testimonials are powerful drivers of a firm's reputation. For this reason, those responsible for marketing are searching for such good looking, famous, trustworthy and successful celebrities. Through these properties the emotions join a product's consumption. Consumers need the testimonials now because they are frustrated by the uncertainty of everyday life, so as a survival strategy they need role models and values. The celebrities therefore play an important role not only for advertising but also for the daily lives of consumers. The role models, their behavior, and thus the products used by them, simplify people's orientation in life and make it easier to decide. For this reason, the testimonial advertising works.

The stars are also a communication tool for companies. They have the potential to increase market awareness and revenue, making ads effective in this way. Besides, celebrities carry with them their own experience which results in a closer and more familiar relationship between them and consumers. Very often, customers see the celebrity endorsers as part of their own lives and that is why they feel free to react and express opinions about them. Sometimes they're inspired by the public person's attitude, feelings or behavior (Bagozzi \& Dholakia, 2002).

Nevertheless, marketers continue to search for ways to quantify and improve the effectiveness of their advertisements through researching the effects of celebrity endorsements on consumer behavior. Another suggestion for advertisers is to include celebrities in the picture of the banner, as this usually attracts immediate attention from consumers. By matching a brand with a celebrity, a brand can exploit specific and beneficial secondary brand associations from a celebrity and gain consumer awareness, pass positive associations related to the celebrity onto the brand, create brand image and eventually increase the value of the endorsed brand (Keller, 2008). The fans are interconnected customers, who respond enthusiastically to the brand and create value for the brand (Schau et al., 2009).

Celebrity endorsements contribute to higher recall rates for ads (O'Mahony, 1997; Meenaghan, 1998) and to better communication with potential customers by creating ties 
between consumers and the advertised brand (Atkin and Block, 1983; Sherman, 1985). In addition, famous people help break down cultural barriers (Mooij, 2004), help reposition brand and company pictures (Till and Shimp, 1998), and eventually increase the sales of supported products (Kaikati, 1987). The announcement of a celebrity endorser deal has been found to have a positive effect on stock returns, rendering celebrity investments worthwhile.

Celebrities are human brands-their on-and off-stage, off-and online, public or private shows are experiments in marketing and branding. Their decisions and values in everyday life are private but they are conducted in public. These acts create identities for brands and branding. Consequently, the human brand identities promote products by granting inanimate brands personality qualities by endorsements and persuasions. They facilitate use by being an idealized customer and commodity vessel (Holmes \& Redmond, 2014).

Byrne et al. (2003) agree that choosing a successful, trustworthy, and internationally recognized individual is the key to success in a structured publicity campaign. In terms of price or quality certain products are not very different. Celebrity plays an important role here: getting customers closer to a specific brand and giving them the right motivation to make the purchasing decision they want. This also occurs because, in advertisements, a well-known person is more compassionate and compelling than an outsider. So before choosing it for an advertising, one should also know the degree of remorse and confession of the testimonial.

Three requirements identify a celebrity as an effective endorsement: beauty, reputation and brand congruency (Erdogan, 1999). A more appealing star more successfully spreads the brand's endorsed message (Till \& Busler, 2000). With a few characteristics such as beauty, charm or an outstanding lifestyle, celebrities enjoy high visibility and are different from ordinary people. According to Friedman and Friedman (1979), celebrity endorser is a person who is recognized in areas other than that of the endorsed product class through the public achievements. The famous people also tend to hit on a higher level of attention, appreciation and loyalty relative to other endorsers. Nowadays, in an era of intense competition, where all businesses strive to remain in the minds of customers and inspire them to buy their products, celebrity endorsement is a real chance. The success can be like a catalyst. "Celebrities as brands" is a challenge for sales. The current notion of handling fame is far from ideal. Now, this phenomenon is considered only as an instrument of business which brings benefits to a brand. The important fact is that celebrity and company fit. The testimonials must match in with the advertised goods. The appearance of celebrities in an advertisement's message should be specific and not random.

Celebrity beauty may refer to physical attributes or other traits, such as intelligence or lifestyle (Erdogan, 1999), all of which may affect purchasing intentions, brand recall, and brand attitudes (Friedman \& Friedman, 1979; Till \& Busler, 2000).

Celebrity endorsement is also a cash-burning process. This is because the consumers pay a great attention to their social position. They always want the right clothes to wear, the right cocktail to drink, the right perfume to buy. For a lot of consumers, the stars are like a reference group. They search for information, they're drawn by celebrities, they spend time and energy to look like them. It happens because celebrities by their lifestyle and social media presence are icons, respected characters for normal people. All these mean social influence. Therefore, in an identification process, a normal, not famous person tries to imitate a public person to look like her. A customer has the actions of a similar celebrity and buys brands that they promote for forming their own identity.

Brands are investing heavily in getting celebrity endorsements. For starters, until 2020 Adidas signed a contract with Cristiano Ronaldo for $£ 14.2 \mathrm{M}$ per year. LeBron James is the 
NBA's current king of sponsorship, with an estimated \$48 million off-court earnings. Given this infatuation with celebrity endorsement brands, however, the association with a celebrity does not necessarily favor the brands (Zhou \& Whitla, 2013), and a clear understanding of the processes underpinning endorsement effects remains an important target for managers and researchers (Bergkvist \& Zhou, 2016).

Celebrity reputation then affects other indicators of endorsement effectiveness, including

PICBE $\mid 841$ brand, product, and advertisement attitudes, as well as purchasing intentions (Friedman \& Friedman, 1979; Pornpitakpan, 2003; Silvera \& Austad, 2004). Every famous person has been found to be more convincing than another endorser. The stars' success gives them a stronger power of persuasion. Customers tend to make a more favorable purchase decision when a wellknown person is promoting the items. But a balance between celebrity and product must be created, a synergy between these, should not be forced and artificial, but real.

Celebrity recognition is now being used as a tool for contact. A well-chosen celebrity can draw customers to a product or brand, and their attention. The singer Fergie, for example, has shown the customer how many kilograms she has lost, probably with the aid of Weight Watchers (Kotler \& Keller, 2008). Choosing figure from ads, the celebrity has a capital role in this situation. The company's chosen public personality should be famous and made known to the public. Therefore, this must ideally match the promoted products or services.

Celebrity endorsement research focuses specifically on celebrity-brand congruence, which is viewed as a primary prerequisite for the effectiveness of such marketing communication. In this view, the customer acts as an outsider of the celebrity-brand connection, while efficacy of endorsement depends on consumer psychological processes like his identity or social influences.

Celebrity endorsement and social media ads serve as a marketing engagement framework to explore how various actors-advertisers, the press, talent management, broadcast networks, consumers and celebrities themselves-come together to co-create individual brand identities in an assembly of operation. Such interactions, in effect, provide service back to the resources of those stakeholders themselves. The emergence of social media represents a rich source of social reality. Such co-creation platforms serve as discursive and competitive mechanisms to develop, re-create, convince and negotiate identities for social and economic purposes for celebrity stakeholders. Not only do celebrities sell products and brands, they also have a powerful influence on all facets of popular culture and public life, shaping customer attitudes and expectations.

In recent years, the number of stars in the ads has been growing. The advertisers have acknowledged the Celebrity Brand Ambassadors' impact the consumers' buying decisions. They have a strong influence on consumer behavior and inspire consumers to purchase certain goods. Testimonial ads may be broadcast, online, on television, or through social media (Zipporah \& Mberia, 2014).

\section{Methodology of research}

The objective of our research is to determine the attitude of consumers on celebrity endorsement and their impact on the image of the endorsed products. The research has analyzed the factors approached in the literature in order to discover their level of relevance and the way in which companies and brands can choose product endorsers based on these factors. Giving the fact that there is an increased trend of companies using celebrity endorsement, the question remains if celebrities have an impact and influence the buying behavior of the consumer. 
In order to test the objectives, we have developed a questionnaire, including 65 questions about the attitude of consumers regarding different situations related to celebrity endorsement and their impact on the consumer's attitude to endorsed brands. There have been measured the perception of consumer's towards celebrities in general, about the relationship between buying behavior and celebrity endorsement, the overshadowing effect that celebrities tend to have on the brand and the effect of scandals and negative news on endorsed products. The perception and attitudes of consumers have been measured with the help of a Likert scale, having values between 1 (total disagreement) and 7 (total agreement). In this paper we will focus on the perception of celebrities and their impact on the consumer's attitude towards endorsed brands. The sample of the survey consisted of 120 consumers with different backgrounds regarding age, gender and income.

\section{Results and discussions}

The first analyzed aspect referred to the daily behavior of consumers and their interest in celebrity news. It resulted in women having an average of 3.65 and men of 2.75 . Both perception have average values, showing an average declared interest in celebrities, yet with higher values for women in comparison to men. It is clear that women tend to read news about celebrities more often and are interested in their kind of lifestyle. It was surprising that the average was still so big in the case of men, which are mostly known for hating this kind behavior especially around woman who like to talk and gossip about celebrities.

Afterwards, there has been analyzed the age groups which are predominantly interested in reading news about celebrities. It resulted that people younger than 30 years old were more eager to read news with an average of 3.67, while people older than 30 years old were not so interested, with an average of 2.81. Up until here, all results were expected, because it is normal that younger people are more involved with the lifestyle of celebrities and are also more interested in brands (Popa \& Pelau, 2016). Another important thing, is the influence of the salary on the time and interest for celebrities. It is interesting to find out if people with higher salaries tend to invest more or less time in reading news about celebrities. The results of our research show that people with higher salaries tend to read less news about celebrities, while people with a smaller salary are more interested in their lifestyle. This result can be due to the fact that people with bigger salaries have more work to do and less time to get involved in something so trivial. In table 1, there can be observed the results of the research, by comparing the average perceptions of men and women. 
Table 1. Attitude of women and men regarding celebrity endorsed products

\begin{tabular}{|l|l|c|c|}
\hline & & $\begin{array}{c}\text { Average } \\
\text { women }\end{array}$ & $\begin{array}{c}\text { Average } \\
\text { men }\end{array}$ \\
\hline 1 & Behavior regarding the everyday interaction with celebrities & 3.65 & 2.75 \\
\hline 2 & Products endorsed by celebrities have a better quality & 3.01 & 2.02 \\
\hline 3 & Products endorsed by celebrities have a better image & 4.35 & 3.05 \\
\hline 4 & Celebrities are a guarantee for the quality of endorsed products & 2.92 & 2.16 \\
\hline 5 & The products endorsed by celebrity are luxury brands & 3.65 & 2.82 \\
\hline 6 & $\begin{array}{l}\text { Products endorsed by celebrities have a better image according to my } \\
\text { social group }\end{array}$ & 4.30 & 2.55 \\
\hline 7 & I have a better social status if I use products endorsed by celebrities & 3.91 & 2.47 \\
\hline 8 & I buy a endorsed product, only if I like the celebrity & 2.63 & 2.54 \\
\hline 9 & Ilike a certain products only because it is endorsed by a celebrity & 2.48 & 1.88 \\
\hline 10 & I don't believe that celebrities who endorse products, also use them & 5.28 & 5.57 \\
\hline 11 & I don't believe statements made by celebrities & 4.97 & 4.47 \\
\hline
\end{tabular}

Another goal of our research has been to find out what the relationship between their opinion on celebrities and the products that they are endorsing. The consumers have been asked if they were believing that products which are endorsed by celebrities have a better quality and a better image. The majority of the consumers perceive that the products endorsed by celebrities have a better image, but not necessarily a better quality. In both cases the women consider more, that the products endorsed by celebrities have a better image (4.35) and a better quality (3.05), in comparison to men (3.05 for image and 2.02 for quality). For both items, the perception has an average or under average $(<4)$ value. More than just the perception of quality or image, we have tested if the celebrities represent a guarantee for the quality of the endorsed products. None of the consumers have agree to this affirmation, with an average for women of 2.92 and average for men of 2.16. Women got a higher average but was still not enough to conclude that they were believing the affirmation.

The association with luxury and social status, is another aspect that we have analyzed in our research. On the affirmation regarding the association of celebrity endorsed products with luxury, women had an average of 3.65, meaning that they have agreed with the affirmation, while men have had an average of 2.82, meaning that they have not agreed with it completely. This is probably due to the fact that they do not believe that all products endorsed by celebrities are luxurious products, but can also be basic products. It was very interesting to observe that even if men and women are aware of the fact that products which are endorsed by celebrities, have a better image and might present themselves as luxurious, they do not necessarily have a better quality than other products and they do not represent a guarantee of seriousness and efficiency.

The next thing that we have analyzed, is the affirmation that people believe that products which are endorsed by celebrities, are better seen by their acquaintances and relatives. This means that people buy products endorsed by celebrities, with the purpose of having a better image and a higher appreciation in the social group. This affirmation has a higher average in case of women (4.3), meaning that they believe that using these type of products will make them look better in the eyes of the people they know. This can be easily seen in the everyday life, when women take more care of the designer dresses they wear, probably with the hope of having a better image. On the other hand, men rather disagree with this affirmation, with an average of 2.55. Men give less importance to the way their social group associates them with famous 
celebrities. The same applies for the affirmation regarding the better social status induced by celebrity endorsed products. Women agree to this items related to the social status (3.9) less than they do for the image created in the social group (4.3). According to these affirmations, women are not necessarily interested in their social status in general, but more to make a good impression on their friends and acquaintances. On the other hand, men care even less about their social status, acquired by wearing or using celebrity endorsed products (2.47). It is interesting to observe, that although the consumers are fully aware of the fact that celebrity endorsed products are not necessarily better in terms of quality, they do have a better image and therefore they provide to their owner a better image and a higher status in their social group. The increase of status appears to be the most important factor for choosing celebrity endorsed products.

The next analyzed items refer to the association between celebrity and products. It has been analyzed if consumers buy a certain product only if they like the celebrity or if they buy it only because it is endorsed by a celebrity. In both cases, men and women have obtained an average answer that was below 3, meaning that they do not agree with either one of the affirmations. In the case of buying a product only if they liked the celebrity, women got an average of 2.63, while men got an average of 2.54. In the case of buying a product only because of the influence of the celebrity, women got an average of 2.48 and men an average of 1.88 . This shows that even though, liking or not liking the celebrity does not necessarily have a big impact on the purchase intention, people are not necessarily feeling obligated to buy a product just because it is endorsed by a celebrity.

The next affirmation that we have discussed is about the fact that consumers are not always believing all the statements that celebrities are making about some products. Moreover, consumers do not believe that celebrities are also using the products that they are endorsing. This phenomenon can happen because of a multitude of factors. For example it might indicate that the level of expertise from the celebrity is not high enough for people to take it as a credible source. Moreover, credibility and trustworthiness also come in question. Celebrities usually make endorsements for more companies and products. The more products they are endorsing, the smaller their credibility gets, because of the fact that people do not know anymore which products are really good and efficient, or if the celebrity has hidden motives behind the endorsement, like for example financial gain. That is why, when a celebrity makes multiple adverts just to get more money, consumers sense it and they do not perceive the celebrity as a credible source anymore. This happens a lot if the match between the celebrity and the brand is not perfect and it affects both the celebrity and the brand, resulting not only in a decrease on the purchase intention of the consumers, but also in lack of trustworthiness for the future. In our research, both female and men have strongly agreed with both affirmations, having an average higher than any other analyzed items. For the first item regarding the fact that they do not believe celebrities who endorse products, also use them, females got an average of 5.28 while men got an average of 5.57, meaning that men believe even stronger that celebrities are just endorsing products for money and that they are not necessarily using them. For the second item, which has analyzed the item regarding believing the statements made by celebrities about certain products, females got an average of 4.97 and men an average of 4.47. Although the average is smaller in comparison to the other affirmation, it still shows the strong opinion of females and males who do not believe the statements that celebrities are making about products. This can mean that even though sometimes people are believing the statements that celebrities are making, which apparently happens not very often, they still do not believe that celebrities are also using those products. 


\section{Conclusion}

The results of our research show that celebrity endorsement has an important impact on the social status of the consumer using or wearing the endorsed product. Celebrity endorsement is less used in order to be a guarantee for the quality of a product, but it is more associated with a certain lifestyle. For this reason it is important that celebrity endorsement should be associated with a certain lifestyle or behavior in using the endorsed product. Taking for instance the advertisement for a coffee. It is not the quality and taste of the coffee that are promoted, but the atmosphere and the context in which the coffee is consumed. The same happens in the case of perfumes of cosmetics. It is impossible to transpose the smell of a advertised perfume in the advertising, but the atmosphere and the glamour of the situation in which it is used.

Another aspect is the fact that women have a more favorable attitude towards celebrity endorsement. This can be explained by the fact that women have in general a stronger orientation towards communication and social issues. Therefore they might be more interested in the happening of their extended social circle, including the one of the famous persons appearing in the media.

The results of the research confirm that celebrity endorsement is an important branding instrument, in world characterized by an inflation of information, news and advertising. Therefore it is important to use celebrities in order to attract the attention towards certain advertisings, but in the same time, it is important to use them wisely in order to have the desired result. For this reason the research of celebrity endorsement is important for achieving the best performance out of the match between celebrities and brands.

\section{References}

Atkin, C., Block, M. (1983). Effectiveness of celebrity endorsers. Journal of Advertising Research, 23 (1), 57-61.

Bagozzi, R. P.; Dholakia, U.M. (2002). Intentional social action in virtual communities. Journal of Interactive Marketing, 16(2), 2-21.

Bergkvist, L., \& Zhou, K. Q. (2016). Celebrity endorsements: A literature review and research agenda. International Journal of Advertising, 35(4), 642-663.

Boffard, R. (2014). "The value of celebrity endorsements". BBC News Business. Retrieved February 3, 2016, from: http://www.bbc.com/news/business-30392829

Byrne, A.; Whitehead, M.; Breen, S. (2003). The naked truth of celebrity endorsement, British Food Journal, 105 (4/5), 288-296.

Centeno, D.; Wang J.J. 2017. Celebrities as human brands: An inquiry on stakeholder-actor cocreation of brand identities, Journal of Business Research 74, 133-138.

Doss, S.K. (2011). The transference of brand attitude: the effect on the celebrity endorser. Journal of Management and Marketing Research, 7, 1-11.

Erdogan, B. Z. (1999). Celebrity endorsement: A literature review. Journal of Marketing Management, 15(4), 291-314.

Erdogan, B.Z., Baker, M.J., Tagg, S. (2001). Selecting celebrity endorsers: the practitioner's perspective. Journal of Advertising Research, 41(3), 39-48.

Friedman, H. H.; Friedman, L. (1979). Endorser effectiveness by product type. Journal of Advertising Research, 19(5), 63-71.

Holmes, S.; Redmond, S. (2014). Socialising celebrity. Celebrity Studies, 5(3), 223-224. 
Kaikati, J.G. (1987). Celebrity advertising: a review and synthesis. International Journal of Advertising, 6 (2), 93-105.

Keller, K.L. (2008). Strategic Brand Management: Building, Measuring and Managing Brand Equity. Prentice Hall, New Jersey.

Kotler P.; Keller, K.L. (2008). Managementul Marketingului, Teora (5th Ed.).

Lazar, L; Nistoreanu, B. (2019). Consumers' perception on celebrity endorsement according to

PICBE | 846 their age, Proceedings of the 5th International Conference on New Trends in Sustainable Business and Consumption (BASIQ), Bari, Italy, pg. 618-624.

McCracken, G., (1989). Who is celebrity endorser? Cultural foundations of the celebrity endorsment process, Journal of Consumer Research, 16(3), 310-321.

Mooij, M. (2004). Consumer Behavior and Culture, Consequences for Global Marketing and Advertising. Sage Publications, London.

Nistoreanu, P.; Pelau, C.; Lazar, L. 2019. Product versus Celebrity - An eye-tracking experiment for the determination of the attention-catcher in advertising, Proceedings of the 13th International Conference of Business Excellence (ICBE), (in press).

O’Mahony, S., Meenaghan, T., 1997/1998. The impact of celebrity endorsements on consumers. Irish Marketing Review, 10 (2), 15-24.

Pop, N.Al. (2018), Quo Vadis Romanian Marketing: The Future and Contribution of the Romanian Community, in: Vaduva S.; Wilt, R.; Fotea, I.; Vaduva L.P. (2018): Civil Society: The Engine for Economic and Social Well-Being, Springer.

Popa, A.; Pelau, C. (2016). Differences in the clothing brand perception depending on generation, Industria Textila, 4/2016, 260-264.

Pornpitakpan, C. (2003). Validation of the celebrity endorsers' credibility scale: Evidence from Asians. Journal of Marketing Management, 19(1-2), 179-195.

Schau, H. J.; Muñiz, A. M.; Arnould, E.J. (2009). How brand community practices create value. Journal of Marketing, 73(5), 30-51.

Silvera, D. H.; Austad, B. (2004). Factors predicting the effectiveness of celebrity endorsement advertisements. European Journal of Marketing, 38(11/12), 1509-1526.

Till, B. D., \& Busler, M. (2000). The match-up hypothesis: Physical attractiveness, expertise, and the role of fit on brand attitude, purchase intent and brand beliefs. Journal of Advertising, 29(3), 1-13.

Till, B.D., Shimp, T.A., 1998. Endorsers in advertising: the case of negative celebrity information. Journal of Advertising 27 (1), 67-82.

Tremblay, V.J., Polasky, S., 2002. Advertising with subjective horizontal and vertical product differentiation. Review of Industrial Organization, 20(3), 253-265.

Zhou, L., \& Whitla, P. (2013). How negative celebrity publicity influences consumer attitudes: The mediating role of moral reputation. Journal of Business Research, 66(8), 1013-1020.

Zipporah, M.M.; Mberia, H. (2014), The Effects OF Celebrity Endorsement in Advertisements, International Journal of Academic Research in Economics and Management Sciences, 3(5) 2014. Retrieved from: http://hrmars.com/hrmars_papers/

The_Effects_OF_Celebrity_Endorsement_in_Advertisements.pdf (accessed on: 3.01.2019). 